\title{
Oxidation ditch process using curved blade rotor as aerator
}

\author{
${ }^{1 *}$ S. B. Thakre; ${ }^{1}$ L. B. Bhuyar; ${ }^{2}$ S. J. Deshmukh \\ ${ }^{1}$ Department of Mechanical Engineering, PRM T and R., Badnera District, Amravati (M.S), 444607, India \\ ${ }^{2}$ Department of Civil Engineering, PRM T and R., Badnera District, Amravati (M.S), 444607, India
}

Received 27 June 2008; $\quad$ revised 18 August 2008; accepted 24 November 2008; available online 10 December 2008

\begin{abstract}
Oxidation ditch process is used to treat the municipal and domestic sewage. The untreated sewage generates fouling smell, harmful bacteria, etc. which is hazardous for public health and degrades the environment by librating noxious gases. This paper examines the use of curved blade aerator for oxidation ditch process. The rotor, which controls the aeration, is the main component of the aeration process. Therefore, the objective of this study is to find out the variations in overall oxygen transfer coefficient and aeration efficiency for different configurations of aerators by varying the parameters like speed of aerator, depth of immersion and blade tip angles so as to yield higher values of overall oxygen transfer coefficient and aeration efficiency. Four aerators of different configuration were developed and fabricated in the laboratory and were tested for above mentioned parameters. A mathematical model is developed for predicting the values of $\mathrm{k}_{\mathrm{L}} \mathrm{a}$ and aeration efficiency which has $\mathrm{R}^{2}$ values of 0.97 and 0.99 for experimentally determined and calculated values. In laboratory studies, the optimum value of overall oxygen transfer coefficient and aeration efficiency were observed to be $10.33 / \mathrm{h}$ and $2.269 \mathrm{~kg} \mathrm{O} / \mathrm{kWh}$ for aerator speed of $48 \mathrm{rpm}, 5.5 \mathrm{~cm}$ depth of immersion and $47^{\circ}$ blade tip angle for curved blade aerator.
\end{abstract}

Key words: Dissolved oxygen, configurations, overall oxygen transfer coefficient, power, aeration efficiency

\section{INTRODUCTION}

Oxygen transfer, the process in which oxygen is transferred from the gaseous to liquid phase, is a vital part of the waste water treatment process (Metcalf and Eddy, 2004). Because of low solubility of oxygen and consequent low rate of oxygen transfer, sufficient oxygen to meet the requirement of aerobic waste does not enter through normal surface air water interface.

To transfer the large needed quantities of oxygen, additional interfaces are created by employing aeration process (Dudley, 1995; Gillot and Heduit, 2000). The creation of additional interfaces enhances the rate of oxygen transfer so that the dissolved oxygen level gets raised to allow aerobic bacteria to reduce biochemical oxygen demand of the effluent (Kumaran, 1992; Abusam et al., 2002). To provide the required amount of oxygen, an aeration system is always needed. Aeration is usually the single largest cost in a wastewater treatment system comprising as much as $50-90 \%$ of the total energy requirements of a secondary wastewater treatment plant (Wasner et al., 1977). Dissolved oxygen (DO) concentration is one of the most important water quality parameters affecting the

*Corresponding Author Email: sbthakre2007@rediffmail.com Tel.: +9422 59 833; Fax: +9107 21681337 quality of wastewater. Various types of aeration systems have been developed over the years to maintain the desired level of DO concentration in the wastewater as an effort to improve the energy efficiency of the oxygen mass transfer process. The three basic categories of aeration methods are :

1. Surface or mechanical aeration method which increase interfacial area by spraying water droplet into the air; 2. Diffused aeration methods which release air bubbles beneath the water surface;

3. Combined and turbine aeration methods which introduced large air bubble into water and reduced their sizes mechanically.

Out of these three, the mechanical surface aerators are widely used because they offer better efficiency, as well as convenience in operation and maintenance (Abusam et al., 2001; Rao and Kumar, 2007). Further, oxygen transfer rate from gas to liquid phase is dependent on various factors for given method of aeration such as dynamic variables like speed, mixing intensity, turbulence and geometrical parameters like size and number of blades, depth of flow, etc. and physicochemical properties of the liquid (Nakasone and Ozaki, 1995). Even though the designer or operator can 
fix or control some of these parameters, successful design requires the knowledge of the effect of all such parameters on reaeration rate. A wide variation in performance of aerators in terms of standard aeration efficiency was found, like, Taiwanese aerator $(1.17 \mathrm{~kg}$ $\mathrm{O}_{2} / \mathrm{kWh}$ ), Japanese aerator ( $1.03 \mathrm{~kg} 0_{2} / \mathrm{kWh}$ ) and Auburn university design (2.25 kg 0 $/ \mathrm{kWh}$ ) (Busch et al. 1974; Boyd and Watten 1989; Boyd, 1998; Colt, 2000a; 2000b). Ahmad and Boyd (1988) provided optimum designs of paddle wheels and Moulick et al. (2002) used similarity criteria in predicting the oxygen transfer performance of paddle wheel aerators. The centrifugal surface aerator along with the paddle wheel surface aerator had been traditionally used in wastewater treatment (Stukenberg et al., 1977; ASCE, 1997). For proper aeration, i.e. proper mixing of DO throughout the water volume, Elliott (1969) suggested the aerator power-to-water volume ratio to be less than $0.1 \mathrm{~kW} / \mathrm{m}^{3}$ while APHA (1980) mentioned that the above ratio should lie within $0.01-0.04 \mathrm{~kW} / \mathrm{m}^{3}$. However, the water volume used in the aeration studies, conducted so far, has not been quantified properly. In the field of wastewater treatment, many investigators have successfully made use of the theory of dimensional analysis and obtained optimal geometric similarity of horizontal rotor aerators under different conditions (Schmidtke and Horvath 1977; Zlokarnik 1979; Ognean 1993). Rao (1999) presented the occurrence of scale effects due to the Reynolds and the Froude laws of the aeration performance under geometric similar conditions.

The criterion of power per unit volume was found to be very useful in geometrically similar systems for scale-up of horizontal rotor aerators (Horvath, 1984; Simha, 1991; Rao, 1999).

The present work focuses on development of unique configuration of aerator which should provide higher values of overall oxygen transfer coefficient and aeration efficiency with minimum power $(\mathrm{P})$ consumption. The experimental apparatus of the oxidation ditch (OD) with different developed aerators were installed in the research laboratory of mechanical engineering department. The experimental work was completed on March 2008.

\section{MATERIALS AND METHODS}

The aeration experiments were conducted in oxidation ditch of demension $2.5 \mathrm{~m} \times 0.35 \mathrm{~m} \times 0.2 \mathrm{~m}$. The experimental setup mainly consists of an oxidation ditch, D.C. motor (0.25 H.P, 1 Amp) with variable speed controller, digital wattmeter (range 0-200 W), dissolve oxygen meter, thermometer and digital tachometer. Curved blade aerator (CBR) was fabricated using impeller fans made up of fiber and used in centrifugal pump, available in market the size of $23 \mathrm{~cm}$ in diameter. 12 small fins the size of $5 \mathrm{~cm} \times 3 \mathrm{~cm}$ are mounted on the fan disc in such a way that the effective diameter of the disc becomes $26 \mathrm{~cm}$. A fiber pipe of 1.5 inch $\times 2$ inch $\times 3$ inch of appropriate length was cut into pieces such that 24 equal strips the length of $14 \mathrm{~cm}$ and width of $4 \mathrm{~cm}$ were yielded from each pipe. This was done to change the blade angles. A pair of fan disc was taken and thus the fabricated strips were screwed on projected fins of the fan discs. The strips were screwed in such a way that the projected length of the strip over the disc fins was $1.5 \mathrm{~cm}$ and thus the diameter of rotor was equal to $29 \mathrm{~cm}$. This assembly of aerator was fastened tightly to the shaft and then fixed in the bearings provided on the collars or hubs. The depth of immersion (DOI) is varied from $4.8 \mathrm{~cm}$ to $7.2 \mathrm{~cm}$ and the speed is varied from $36 \mathrm{rpm}$ to $60 \mathrm{rpm}$. The performance is evaluated for each kind of configuration of rotor aerator such as aerator's blade angle at different speeds and at different DOI with respect to power consumption.

\section{Aeration test}

The used deoxygenation-oxygenation procedure was the non steady state reaeration test (APHA, 1980; Moulick et al., 2005). The test water was deoxygenated with $10 \mathrm{mg} / \mathrm{L}$ of sodium sulphite, but cobalt chloride was not used during test, since it is considered hazardous to human health (Cancino, 2004). After maintaining DO between $0.0-0.1 \mathrm{mg} / \mathrm{L}$ for about $5 \mathrm{~min}$ both the aerator were put in operation at the same moment and at the same rotational speed and immersion depth.

Increase in DO concentration was measured by DO probe at the surface of water and at the half depth from the surface. The readings were taken at equal time intervals until DO increased from $0 \%$ saturation to at least $90 \%$ saturation. The dissolved oxygen saturation concentration $\left(\mathrm{C}_{\mathrm{s}}\right)$ used for calculating the $\mathrm{K}_{\mathrm{L}}$ a was estimated using the highest dissolved oxygen concentration from each test.

\section{RESULTS AND DISCUSSION}

Out of the various factors which may affect aeration or dissolve oxygen level such as time of aeration and depth of immersion, speed of aerator and blade tip angle mounted on the aerator are mainly considered. The temperature of the water was kept constant at $20^{\circ} \mathrm{C}$. 
For every set of observation, overall oxygen transfer coefficient $\mathrm{K}_{\mathrm{L}} \mathrm{a}$, which is a measure of aeration, is computed and its behavior is studied with respect to other variables keeping the variables constant at that time. $\mathrm{K}_{\mathrm{L}} \mathrm{a}$, the overall oxygen transfer coefficient, is the rate of oxygen transfer for a unit saturation deficit and is constant for a particular system of aeration.

Assessment of overall oxygen transfer coefficient of an aeration system is one of the most important factors. Underestimating the oxygen transfer rate results in an overdesigned system which may be energy intensive and expensive to operate. On the other hand, overestimating the oxygen transfer rate results in inadequate oxygen supply, which in turn, reduces efficiency.

Mathematical model for measurement of overall oxygen transfer co-efficient $\left(\mathrm{K}_{\mathrm{L}} \mathrm{a}\right)$ is defined as:

Aeration is transfer of air or oxygen in the water (Mueller et al., 2002). The oxygen transfer through water is governed by Ficks' Law of diffusion and is a liquid film controlled process. In aeration, the rate of oxygen transfer was expressed earlier as:

$$
\mathrm{dc} / \mathrm{dt}=\mathrm{K}_{\mathrm{L}} \mathrm{a}\left(\mathrm{C}_{\mathrm{s}}-\mathrm{C}_{\mathrm{t}}\right)
$$

Where, $K_{L} a$ is the rate of oxygen transfer for saturation deficit and it is constant for a particular system of aeration. Therefore, this is referred as measurement of aeration and it forms a good basis of studying the behavior under various variables. This is employed in the studies in the unit of $1 / \mathrm{min}$ or $1 / \mathrm{h}$.

The rate of oxygen transfer equation was converted into:

$C_{(t+h)}=C_{t} \cdot e^{-K_{L}^{a} \cdot h}+C_{s}\left(1-e^{-K_{L}^{a} \cdot h}\right)$

This is comparable to the equation of straight line of the form:

$\mathrm{Y}=\mathrm{m} \cdot \mathrm{X}+\mathrm{A}$

Thus, if a plot is drawn between $\mathrm{C}_{(\mathrm{t}+\mathrm{h})}$ and $\mathrm{C}_{\mathrm{t}}$, it would yield a straight line and slope of this line $(\mathrm{m})$ represents the value of $\mathrm{e}^{-\mathrm{K}_{\mathrm{L}} \text { a.h }}$ from which $\mathrm{K}_{\mathrm{L}}$ a can be calculated. Similarly, the intercept on Y-axis (A) represents the term Cs $\left(1-\mathrm{e}_{\mathrm{L}}^{-K_{\mathrm{L}} . \mathrm{h}}\right)$ from which the value of $\mathrm{C}_{\mathrm{s}}$ can be known. Thus, it clearly indicates that in order to determine the value of $\mathrm{K}_{\mathrm{L}} \mathrm{a}$, it must be carried out at a uniform interval of time.

In the present study, the curves have been drawn between $\mathrm{C}_{(\mathrm{t}+\mathrm{h})}$ against $\mathrm{C}_{\mathrm{t}}$ and $\mathrm{h}$ is taken as $15 \mathrm{~min}$. The slope of this line is known and the value of $\mathrm{K}_{\mathrm{L}} \mathrm{a}$ is calculated.

The plot between $\mathrm{C}_{(\mathrm{t}+\mathrm{h})}$ and $\mathrm{C}_{\mathrm{t}}$ is obtained for different configurations of rotor aerator at different speeds, i.e. 36, 42, 48 and $60 \mathrm{rpm}$. The data generated from different

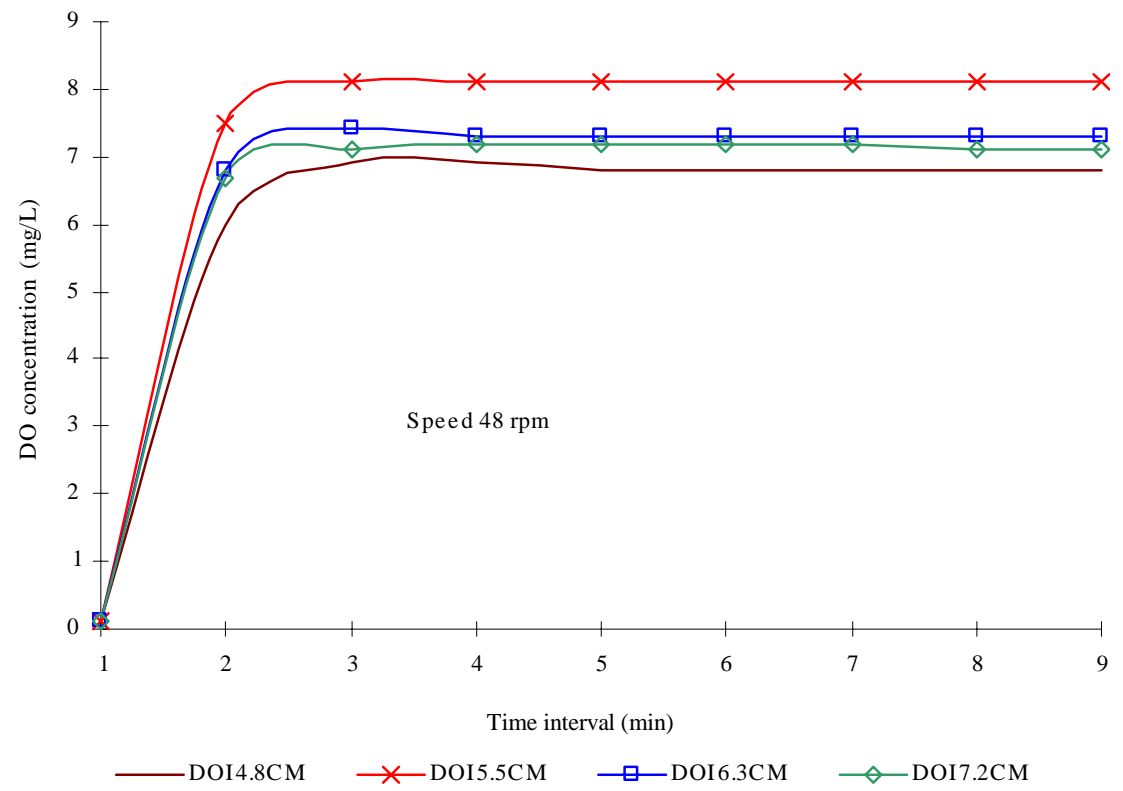

Fig. 1: Variation of DO with time for different depth of immersion and blade tip angle $<47^{\circ}$ 


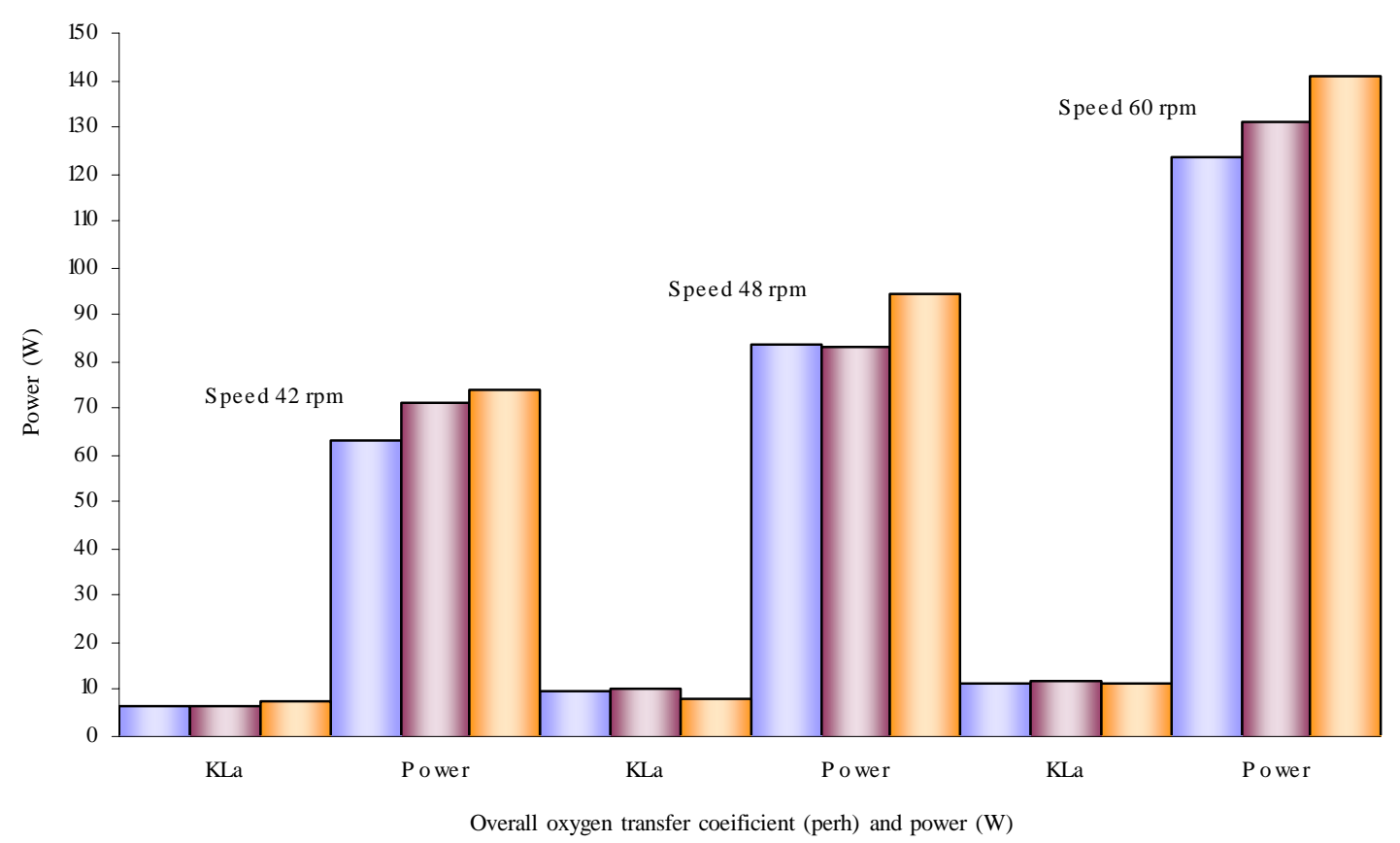

Fig. 2: Variation of $\mathrm{K}_{\mathrm{L}}$ a and power for $\mathrm{CBR}$ in various blade angles, Speeds and depth of immersion $5.5 \mathrm{~cm}$

rotors followed different curves and indicated different values of $\mathrm{K}_{\mathrm{L}} \mathrm{a}$ and aeration efficiency.

Variation of DO with time for various depths of immersion

Fig. 1 illustrates that the increase in DO concentration is very high in first $15 \mathrm{~min}$, then it gradually attains a saturation value pertaining to the performance of the respective aerator. It is observed that the maximum increase in DO concentration, that is from $0.0 \mathrm{mg} / \mathrm{L}$ to $8.2 \mathrm{mg} / \mathrm{L}$ is attended by CBR aerator when the blade tip angle is $47^{\circ}$ and the depth of immersion is $5.5 \mathrm{~cm}$. All the curves were plotted at 48 rpm aerator speed. The literature cited by the author reveals that the optimum performance is generally obtained at blade angle of $45^{\circ}$. Therefore, the above blade angle is chosen.

Variation of $K_{L} a$ and power for various blade angles and speed

Fig. 2, which shows the variation of $\mathrm{K}_{\mathrm{L}}$ a and power for various blade angles and speed with respect to CBR aerator, considers the depth of immersion $5.5 \mathrm{~cm}$ as an optimum value. It is very clear from Fig. 2 that as the power and speed increase, the corresponding values of $\mathrm{k}_{\mathrm{L}}$ a also increase. It is evident from the figure that at a speed of $48 \mathrm{rpm}$, the power requirement is observed to be in the medium range that is $73.8 \mathrm{~W}$, whereas there is a considerable increase in the value of $\mathrm{k}_{\mathrm{L}} \mathrm{a}$ in the tune of $10.33 / \mathrm{h}$. As the power consumption decreases below $73.8 \mathrm{~W}$, the value of $\mathrm{K}_{\mathrm{L}}$ a also decreases correspondingly, which further decreases the aeration efficiency that is not acceptable as per the values quoted by the researchers.

When the power consumption increases beyond $73.8 \mathrm{~W}$, there is a marginal increase in $\mathrm{K}_{\mathrm{t}}$ a value, but aeration efficiency drops sharply from $2.269 \mathrm{~kg} \mathrm{O}_{2} / \mathrm{kWh}$ to $1.37 \mathrm{kgO}_{2} / \mathrm{kWh}$. Because of increase in speed of CBR aerator from $48 \mathrm{rpm}$ to $60 \mathrm{rpm}$, it is observed that splashing of wastewater tackes place outside the ditch, which deteriorates the surrounding atmosphere and thereby causing problems for working personals present at the plant. This may also create problems in driving mechanism as the motor is mounted below the ditch.

Variation in DO for various blade tip angle with time The variation in DO for various blade tip angle with time is shown in Fig. 3.

This figure represents the curves plotted at $42 \mathrm{rpm}$ and $5.5 \mathrm{~cm}$ depth of immersion. Three types of blade tip angles were tested which suggests that maximum 


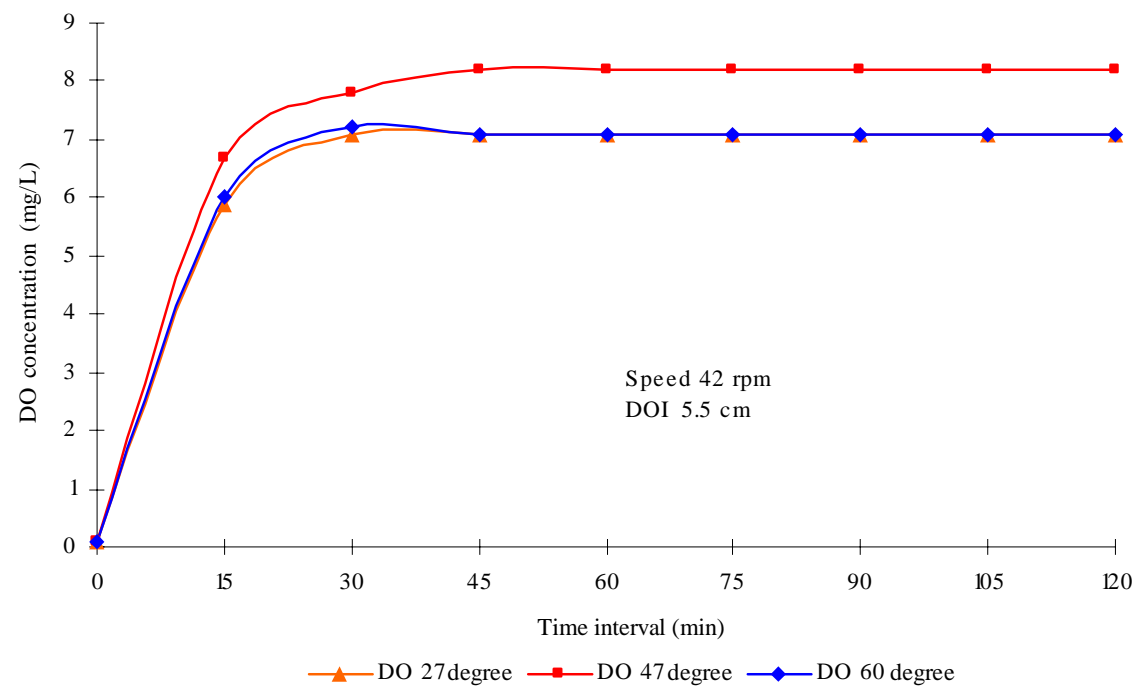

Fig. 3: Variation of DO Vs time for various angles of CBR, speed $42 \mathrm{rpm}$ and DOI - $5.5 \mathrm{~cm}$

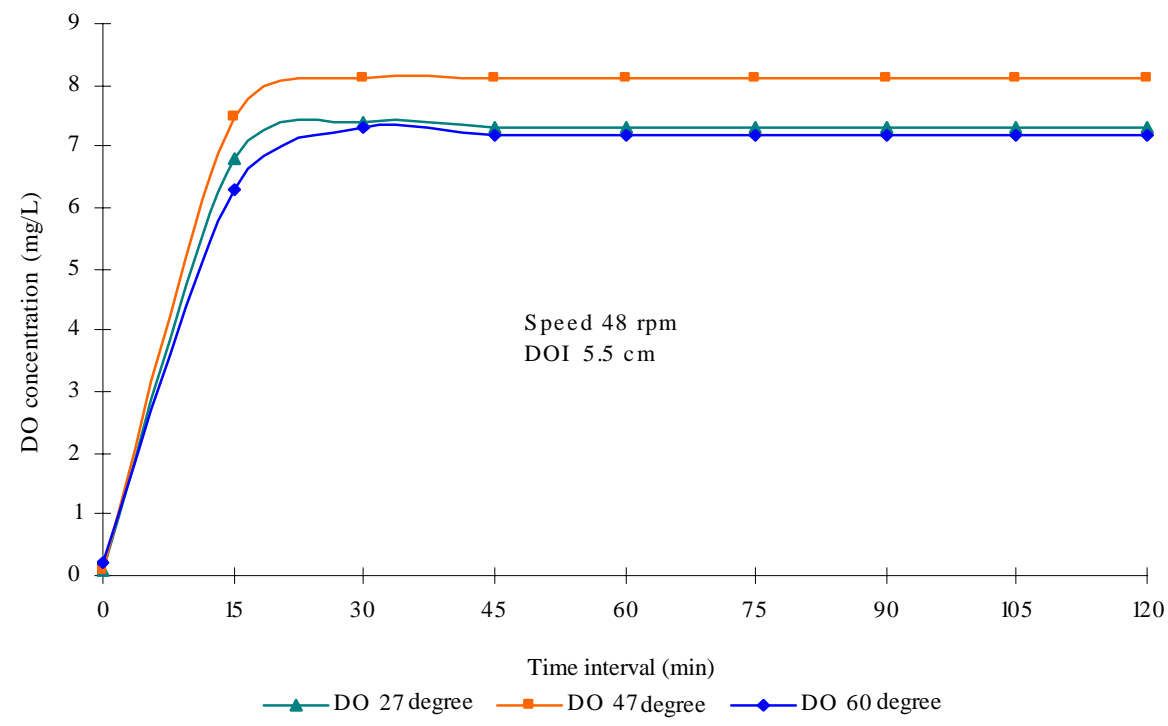

Fig. 4: Variation of DO vs. time in various angles of CBR, speed $48 \mathrm{rpm}$ and DOI $-5.5 \mathrm{~cm}$

DO concentration is achieved when the blade tip angle is at $47^{\circ}$. With this configuration, DO level of 8.2 $\mathrm{mg} / \mathrm{L}$ is attended in $45 \mathrm{~min}$ and thereafter the DO concentration curve remains constant which indicates that the saturation deficit of oxygen is met.

Figs. 4 and 5, which represent the same plot as above, follow the similar trend as that of Fig. 3.
Combined analysis of all the three figures reveals that the optimum performance is recorded at blade tip angle of $47^{\circ}$.

Plot between $C(t+h)$ and $C t$ for determination of $k_{L} a$ As stated earlier, the plot between $\mathrm{C}_{(\mathrm{t}+\mathrm{h})}$ and $\mathrm{C}_{\mathrm{t}}$ will yield a straight line. The slope of the line is known and 
the value of $\mathrm{K}_{\mathrm{L}} \mathrm{a}$ is calculated. The time interval (h) is maintained as 15 min (Fig. 6). The data obtained for different depths of immersiom produced different curves. It is quite evident from the figure that the curve obtained for $5.5 \mathrm{~cm}$ depth of immersion, $48 \mathrm{rpm}$ speed and $47^{\circ}$ blade tip angle yielded maximum value of $\mathrm{K}_{\mathrm{L}} \mathrm{a}$.

The variation in $\mathrm{k}_{\mathrm{L}}$ and required power is presented in Table1. It also suggests that depth of immersion is directly proportional to the power consumption.

On the other hand, the increase in $\mathrm{K}_{\mathrm{L}} \mathrm{a}$ is not so significant. As a golden mean, the value of $\mathrm{K}_{\mathrm{L}} \mathrm{a}$ is finally taken as $10.33 / \mathrm{h}$ when the required power is $73.8 \mathrm{~W}$ and it is observed that the value of AE (aeration efficiency) is the highest for these values.

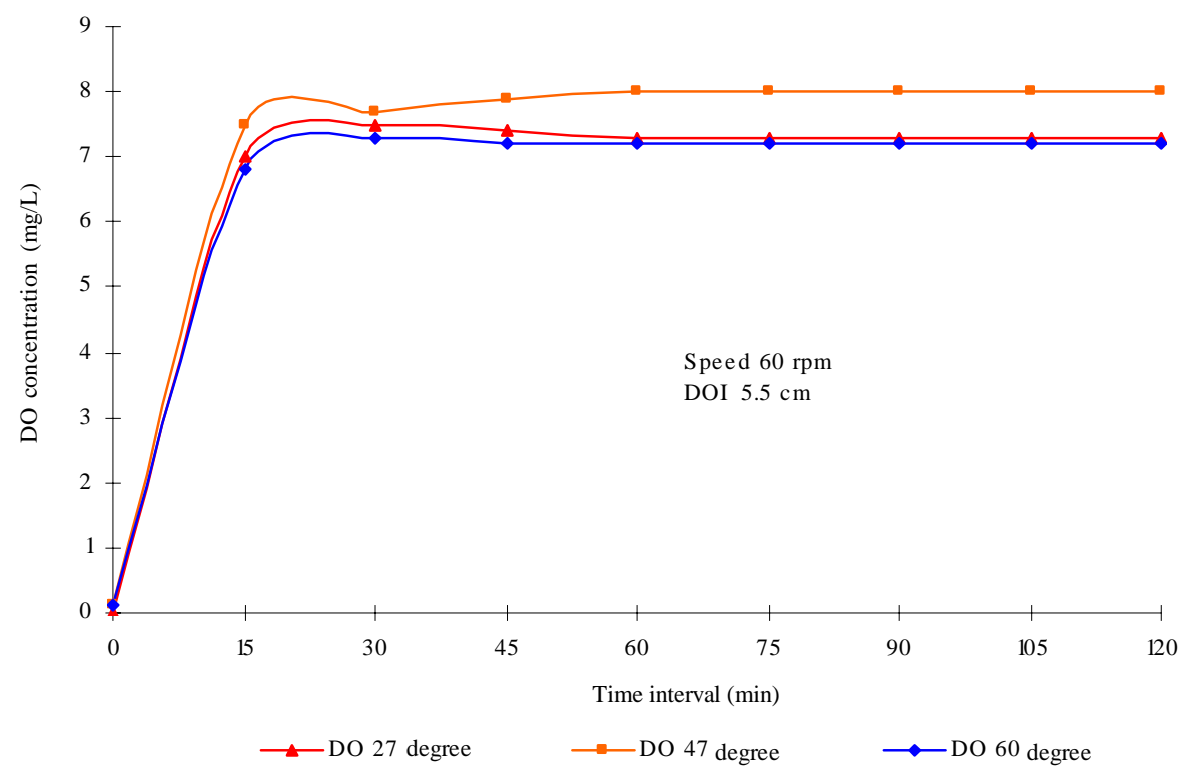

Fig. 5: Variation of DO vs. Time for various angles of CBR, speed $60 \mathrm{rpm}$ and doi $-5.5 \mathrm{~cm}$

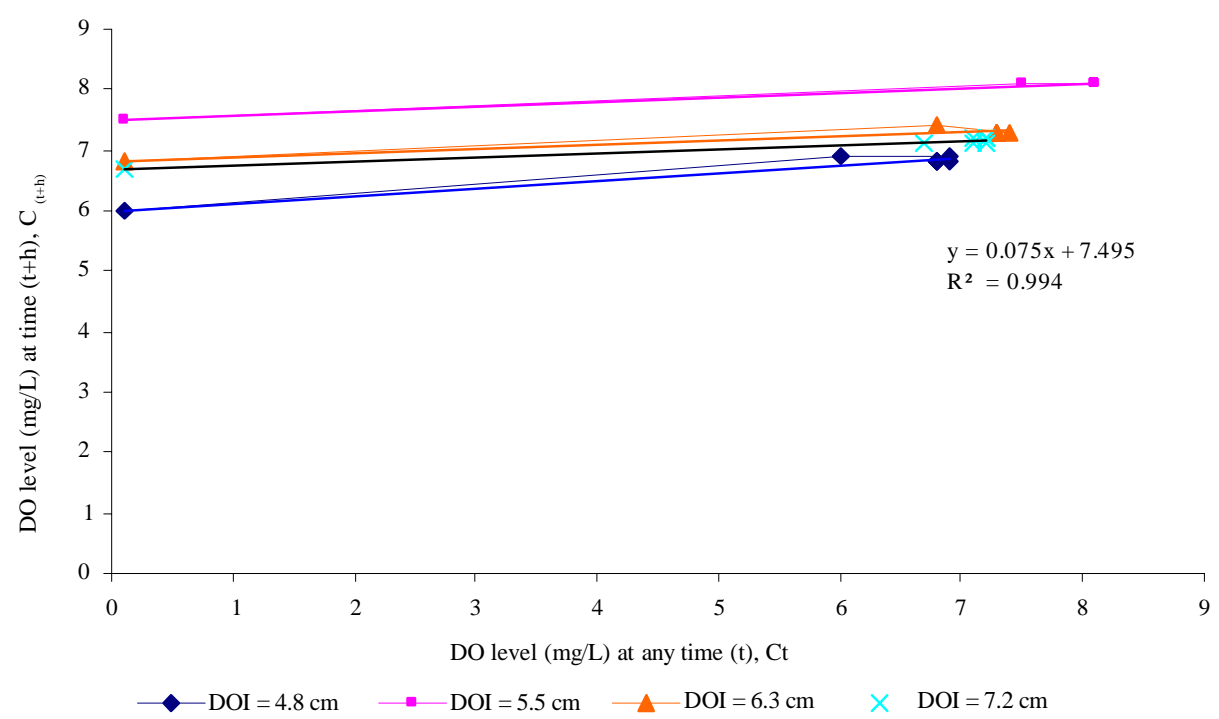

Fig. 6: DO level at time $(t+h)$ vs. DO level at time $(t)$ for determination of $K_{L} a$ 


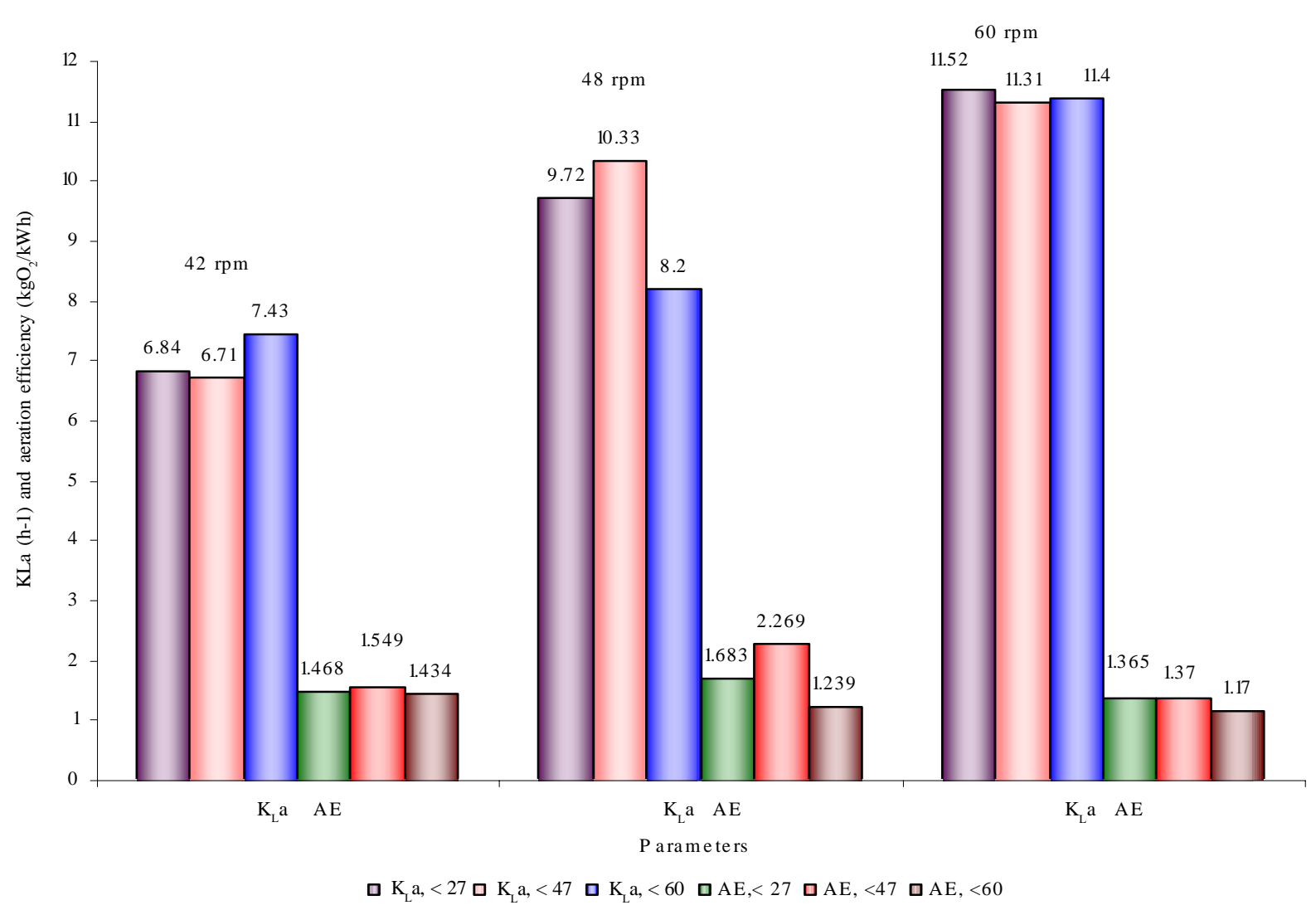

Fig. 7: Variation in $\mathrm{K}_{\mathrm{L}} \mathrm{a}$ and $\mathrm{AE}$ with different blade angles and speeds

Variation in aeration efficiency with respect to power and $K_{L} a$

The performance of aerator is better judged by a parameter known as AE which is defined as the amount of oxygen transferred per unit power. Fig. 7 describes the variations of $\mathrm{K}_{\mathrm{L}} \mathrm{a}$ and $\mathrm{AE}$ for various blades tip angles and speeds. Out of three tested configurations, it can be seen that at $48 \mathrm{rpm}$ and $47^{\circ}$ blade tip angle, the optimum value of $\mathrm{K}_{\mathrm{L}}$ a is observed to be $10.33 / \mathrm{h}$ and recorded the highest value of $\mathrm{AE}$ that is 2.269 $\mathrm{kgO}_{2} / \mathrm{kWh}$. This is because of the AE which is the function of power and as stated earlier the required power increases with increase in speed and depth of immersion. Even though the values of $\mathrm{K}_{\mathrm{L}}$ a at $60 \mathrm{rpm}$ and $27^{\circ}, 47^{\circ}$ and $60^{\circ}$ blade tip angles are more than that of $48 \mathrm{rpm}$, the power required to attend the same is quite higher. Therefore, the $\mathrm{AE}$ values for above configuration and speed decreases drastically to 1.365 , 1.37, $1.17 \mathrm{~kg} \mathrm{O}_{2} / \mathrm{kWh}$ as against 1.683, 2.269 and 1.239 $\mathrm{kgO}_{2} / \mathrm{kWh}$ at speed of $48 \mathrm{rpm}$.

\section{Developed model}

In this paper, the attempts are made to correlate the data generated in laboratory and the data calculated using mathematical model. In this phenomenon, the author has used two models. From the study of the data generated in laboratory, the attempts are made to identify the dependent and independent variables and using Buckingham $\pi$ theorem concept, these variables are interrelated by developing dimensionally homogeneous equations.

Equations may be used with confidence for predicting the $\mathrm{K}_{\mathrm{L}}$ a and power and can be considered as design equations for CBR aerator.

$K_{L^{a}} a=0.000746\left[(N)^{1.768}\left(\frac{h}{D}\right)^{1.038}(\alpha)^{0.031}\right]$

Where,

$\mathrm{K}_{\mathrm{L}}$ a: Overall oxygen transfer coefficient/min 
$\mathrm{N}$ : Speed of aerator in rpm

$\mathrm{h} / \mathrm{D}$ : Ratio of depth of immersion to the diameter of aerator.

$\alpha$ : Blade tip angle in degree.

$P$ : Required power in watts (W).

The calculated values using above models yielded good coefficient of determination $\left(\mathrm{R}^{2}\right)$ with the experimentally observed values which are in good agreement with standard error of estimation. A program in computer programme $\mathrm{C}^{++}(\mathrm{CPP})$ is developed to inter the various influencing parameters mentioned above and are solved by multiple linear regression analysis methods. Figs. 8 and 9 is the plot between experimentally determined values and calculated values from the model formulated for $\mathrm{K}_{\mathrm{L}} \mathrm{a}$ and power, respectively.

It has been estimated that the simulation of Eqs. 1 and 2 predict the values of $\mathrm{K}_{\mathrm{L}}$ a and power with an

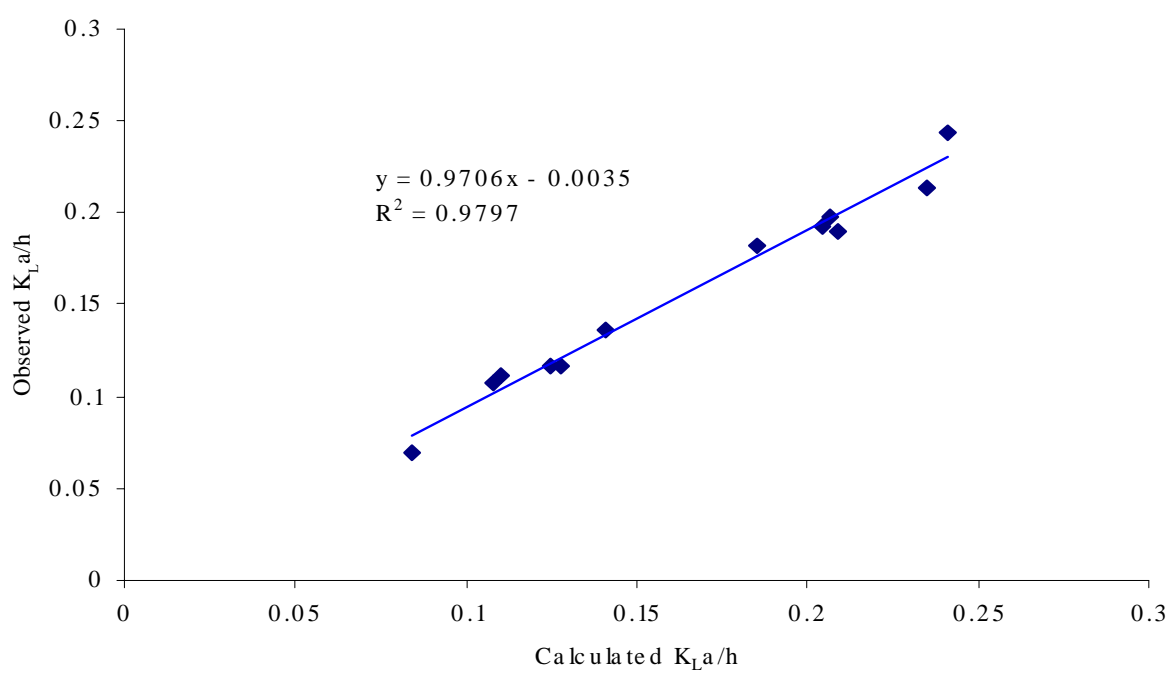

Fig. 8: Relationship between observed and calculated values of $\mathrm{K}_{\mathrm{L}} \mathrm{a}$

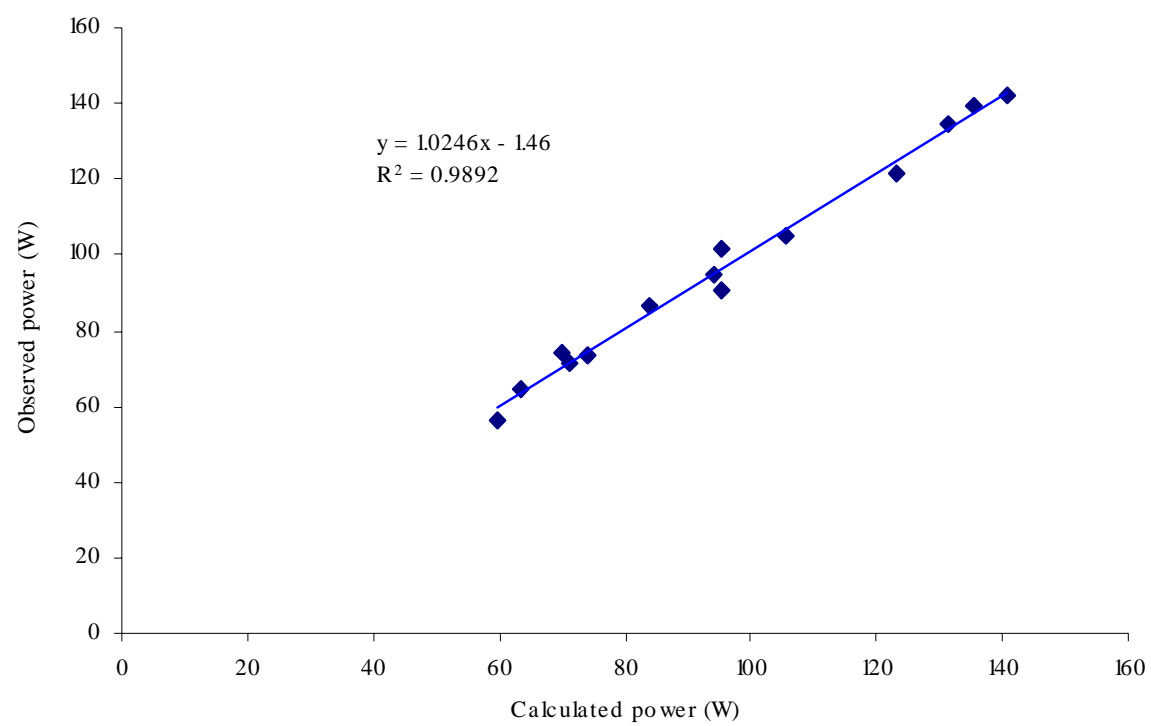

Fig. 9: Relationship between observed and calculated values of power (P) 
$P=0.0694\left[(N)^{2.062}\left(\frac{h}{D}\right)^{1.1412}(\alpha)^{0.1942}\left(K_{L} a\right)^{-0.1729}\right]$

average standard error of estimation of 0.0164 and 7.66 and with $\mathrm{R}^{2}$ values of 0.9797 and 0.9892 , respectively, when compared with experimentally determined values.

Thus, Eqs. 4 and 5 are justifiable by taking into consideration all of the experimental errors.

Therefore, above equations may be used with confidence for predicting the $\mathrm{k}_{\mathrm{L}} \mathrm{a}$ and powe and can be considered as design equations for CBR aerator.

\section{CONCLUSION}

Considering the influence of various parameters simultaneously, it has been observed that to get the maximum value of overall oxygen transfer coefficient $\left(\mathrm{K}_{\mathrm{L}} \mathrm{a}\right)$, following conclusion is justified:

1 . The value of overall oxygen transfer coefficient $\left(\mathrm{K}_{\mathrm{L}} \mathrm{a}\right)$ is proportional to the turbulence created by the aerator motion, i.e. the higher the aerator speed, the greater is the turbulence which results in enhanced value of $\mathrm{K}_{\mathrm{L}} \mathrm{a}$. 2 . The value of overall oxygen transfer coefficient $\left(\mathrm{K}_{\mathrm{L}} \mathrm{a}\right)$ and aeration efficiency depends upon the relative depth of immersion of the aerator in the liquid. At $5.5 \mathrm{~cm}$ depth of immersion, the maximium value has been obtained for AE..

3. The aeration time may be chosen between 30 to 60 $\mathrm{min}$. The lower limits are choosen for the case of $5.5 \mathrm{~cm}$ depth of immersion, higher speed and for blades tip angle of $47^{\circ}$ on the rotor, whereas the higher limit is for the case of lower depth of immersion, lower speeds and for blades angles more or less than $47^{\circ}$.

4. The aeration efficiency which compares the performance of aerators mainly depends on the power consumption of the aerator. In some cases, it is found that even though the value of $\mathrm{K}_{\mathrm{L}} \mathrm{a}$ is higher, the aeration efficiency drops drastically. This is mainly because of the increase in power consumption for that particular set up. For example, at $60 \mathrm{rpm}, 6.3$ depth of immersion and blade tip angle of $27^{\circ}$, the value of $\mathrm{K}_{\mathrm{L}} \mathrm{a}$ is found out to be $12.87 / \mathrm{h}$, but the aeration efficiency drops

Table 1: Variation Of $\mathrm{K}_{\mathrm{L}} \mathrm{a}$ and power with depth of immersion for speed $48 \mathrm{rpm}$

\begin{tabular}{cccc}
\hline No. & Depth of immersion $(\mathrm{cm})$ & $\mathrm{K}_{\mathrm{L}} \mathrm{a} / \mathrm{h}$ & Power $(\mathrm{W})$ \\
\hline 1 & 4.8 & 8.414 & 69.9 \\
2 & 5.5 & 10.33 & 73.8 \\
3 & 6.2 & 10.58 & 93.5 \\
4 & 7.2 & 10.93 & 136 \\
\hline
\end{tabular}

drastically to $1.385 \mathrm{~kg} \mathrm{O}_{2} / \mathrm{kwh}$. This is mainly because the power consumption for this configuration, speed and depth of immersion is $135.3 \mathrm{~W}$. As against, at 48 rpm, 5.5 depth of immersion and blade tip angle of $47^{\circ}$ the value of $\mathrm{K}_{\mathrm{L}}$ a is found out to be $10.33 / \mathrm{h}$., but the aeration efficiency increases sharply to $2.269 \mathrm{kgO}_{2} / \mathrm{kwh}$, because for this configuration, the power consumption is $73.8 \mathrm{~W}$.

5. A simplified simulation of Eqs. 1 and 2 are developed, which can be used to calculate the values of $\mathrm{k}_{\mathrm{L}} \mathrm{a}$ and power for given diameter of aerator (D), depth of immersion (h) blade tip angle $(\alpha)$.

Finally, it can be concluded that aeration can be made more effective by optimizing various factors affecting it like speed of aerator, depth of immersion, blades angles, etc. Also, overall oxygen transfer coefficient $\left(\mathrm{K}_{\mathrm{L}} \mathrm{a}\right)$ and aeration efficiency gives an excellent measure of oxygen transfer efficiency in conjunction with power required by eliminating combined effect of saturation dissolved oxygen level and initial lag in actual oxygen transfer.

\section{REFERENCES}

Abusam, A.; Keesman, K. J.; Meinema, K.; Straten, G. V., (2001). Oxygen transfer rate estimation in oxidation ditches from clean water measurement. water Res., 35 (8), 20582064.

Abusam, A.; Keesman, K. J.; Spanjers, H.; Meinema, K. (2002). Evaluation of control strategies using an oxidation ditch benchmark., water. Sci. Tech., 45 (4-5), 151-158.

APHA, (1980). Standard methods for the examination of water and wastewater, $15^{\text {th. }}$ (Ed.), America Public Health Association, America Water Works Association, and Water Pollution Control Federation, Washington D.C.

Ahmad, T.; Boyd, C. E., (1988). Design and performance of paddle wheel aerators., Aquacult. Eng., 7 (1), 39-62.

ASCE standard (1997). Standard guidelines for in-process oxygen transfer testing. The American Society of Civil Engineers, 18-96, New York.

Boyd, C. E., (1998). Pond water aeration systems., Aquacult. Eng. 18 (1), 9-40.

Boyd, C. E.; Watten, B. J., (1989). Aeration systems in Aquacultural., Crit. Rev. Aquacult. Sci., 1 (3), 425-472.

Busch, C. D.; Koon, J. L.; Allison, R., (1974). Aeration, water quality and catfish production., T. Am. Soc. Agr. Eng., 17 (3), 433-435.

Cancino, B., (2004). Design of high efficiency surface aerators part 2. Rating of surface aerator rotors., Aquacult. Eng., 31 (1-2), 99-115.

Colt, J., (2000a). Design of gas transfer systems for aquaculture, part 2., Aquacult. Mag., 26 (5), 50-55.

Colt, J., (2000 b). Design of gas transfer systems for aquaculture, part 3., Aquacult. Mag., 26 (6), 53-59.

Dudley, J., (1995). Process testing of aerators in oxidation ditches., Water Res., 29 (9), 2217-2219. 
Elliott, J. W., (1969). The oxygen requirements of Chinook salmon., Prog. Fish Cult., 31 (2), 67-73.

Gillot, S.; Heduit, A. (2000). Effect of air flow rate on oxygen transfer in an oxidation ditch equipped with fine bubble diffusers and slow speed mixers., Water Res., 34 (5), 17561762.

Horvath, I., (1984). Modeling in the technology of waste water treatment, Pergamon, Tarrytown, NewYork.

Kumaran, P. (1992). Performance evaluation of an oxidation ditch for phenolic wastewater treatment., Indian J. Environ. Health., 34 (4), 308-317.

Metcalf and Eddy Inc. (2001). Waste water engineering; Treatment disposal and reuse. Tata McGraw Hill. New Delhi, India. American Public Health Association.

Moulick, S.; Mal, B. C.; Bandyopadhyay, S., (2002). Prediction of aeration performance of paddle wheel aerators., Aquacult. Eng. 25 (4), 217-237.

Moulick, S.; Mal, B. C.; Bandyopadhyay, S., (2005). Design characteristics of single hub paddle aerator., J. Environ. Eng. 131 (8), 1147-1154

Mueller, J.; Boyle, W. C.; Ing, H.; Popel, J., (2002). Aeration: Principles and practice No. 11., Water quality management library.
Nakasone, H.; Ozaki, M., (1995). Oxidation-ditch process using falling water as aerator., J. Environ. Eng., 121 (2), 132139.

Ognean, T., (1993). Aspects concerning scale-up criteria for surface aerators., Water Res. 27 (3), 477-484.

Rao, A. R., (1999). Predication rate in square, stirred tanks., J. Environ. Eng. 125 (3), 215-223.

Rao, A. R.; Kumar, B., (2007). Neural modeling of square surface aerators., J. Environ. Eng. 133 (4), 411-418.

Schmidtke, N. W.; Horwath, T., (1977). Scale-up methodology for surface aerated reaerators., Prog. Water Tech. 9, 477493.

Simha, L. U., (1991). Experimental studies on overall oxygen transfer coefficient., Ph.D thesis. Departement of Civil Eng., Indian institute of science, Bangalore, India.

Stukenberg. J. R.; Wahbeh, V. N.; McKinney, R. E., (1977). Experiences in evaluating and specifying aeration equipments., J. WPCF. 66-82

Wesner, G. M.; Ewing, J. J.; Lineck, T. S.; Hinrichs, D. J., (1977). Energy conservation in municipal wastewater treatment., EPA-130/9-77-011, NTIS No. PB81165391,U.S. EPA Res., Washington, D.C.

Zlokarnik, M., (1979). Scale up of surface aerators for waste water treatment., Adv. Biochem. Eng. 11, 157-179.

\section{AUTHOR (S) BIOSKETCHES}

Thakre, S. B., M.E., Department of Mechanical Engineering, PRM T and R., Badnera District, Amravati (M.S), 444607 and Ph.D. research student in engineering and technology at Amravati University, Amravati, India. Email: sbthakre2007@rediffmail.com

Bhuyar, L. B., M.E. Ph.D., Professor and Head of Department of Mechanical Engineering, PRM T and R., Badnera District, Amravati (M.S), 444607, India. Email: lbbhuyar@gmail.com

Deshmukh, S. J., M.E., Department of Mechanical Engineering. PRM T and R., Badnera District, Amravati (M.S), 444607 and Ph.D. research student in engineering and technology at Amravati University, Amravati, India. Email: aryasamir@rediffmail.com

This article should be referenced as follows:

Thakre, S. B.; Bhuyar, L. B.; Deshmukh, S. J., (2008). Oxidation ditch process using curved blade rotor as aerator. Int. J. Environ. Sci. Tech., 6 (1), 113-122. 